\title{
How the Evolution of the UK Annual Data during 1950-2007 relates with the Developments of Macroeconomic Theories
}

\author{
Xi-Yu REN ${ }^{1, a}$ \\ ${ }^{1}$ The University of Manchester, school of social science \\ aXiyu.ren@student.manchester.ac.uk
}

Keywords: Macroeconomic theory, UK Data, Policies 1950-2007.

\begin{abstract}
How the development of the macroeconomic theories and political policies affects the UK macroeconomic data during 1950-2007 were analysed by using unemployment rate, GDP growth rate and consumer price rate as the three basic indicators of macroeconomic performances. Findings indicate that development in theories did relate to macroeconomic performances, but the role is actually very limited. Both the set of external circumstances and how politicians actually implementing the policies are also inseparable to the economic performances in corresponding periods.
\end{abstract}

\section{General Trend of the Data and the Introduction}

Economic performances in different periods in UK seemed have distinctions when different macroeconomic theories took the lead.

As in Fig.1 (Source: (Thomas\&Dimsdale,2016[1])), real-GDP growth rate frequently fluctuated in 1950s-1960s at the period led by Keynesian's "stop-go" policies, until 1974, stagflation happened and Monetarism began its leading period. During 1980s-90s, except the period 1983-1989, all booms in business cycle seemed milder but recessions were severer in 1981 and 1991 which kind of affected by monetarist's monetary targets(Sloman,Wride,\&Garratt,2015[2]). From 1990s2000s, new consensus took the lead and great moderation started.
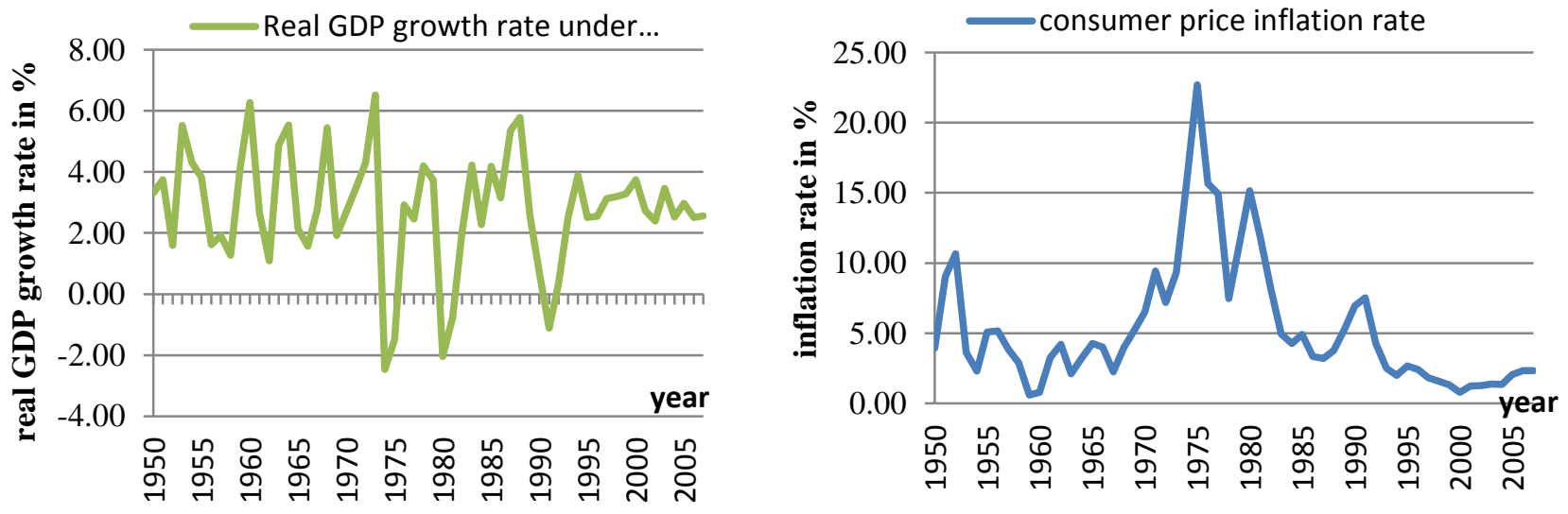

Fig 1. Real GDP growth rate (\%) in UK

Fig 2. Consumer price inflation rate (\%) during 1950-2007 in UK during 1950-2007

Inflation rates in 1950-60s generally fluctuated near 5\% in Keynesian's leading period until it went up in 1968 and reached the peak in 1974's stagflation. Another smaller peak happened in 1981 and followed by milder fluctuations afterwards in 1980s-1992 led by monetarists at around 5\% and period of great moderation held at around 2\%.(Fig. 2)

Unemployment rates were in low level during 1950-60s around 2\% under Keynesian's fullemployment demand-management policy as a golden period. It started to increase since 1970 under stagflation and reached the peak at 1981's recession with a drop in 1989 but still in high level and reached another peak in 1991 's recession while monetarists took the lead, following by decreasing 
since 1994 under the period of new consensus but never reached $2 \%$ as in Keynesian's period again.(Fig. 3)
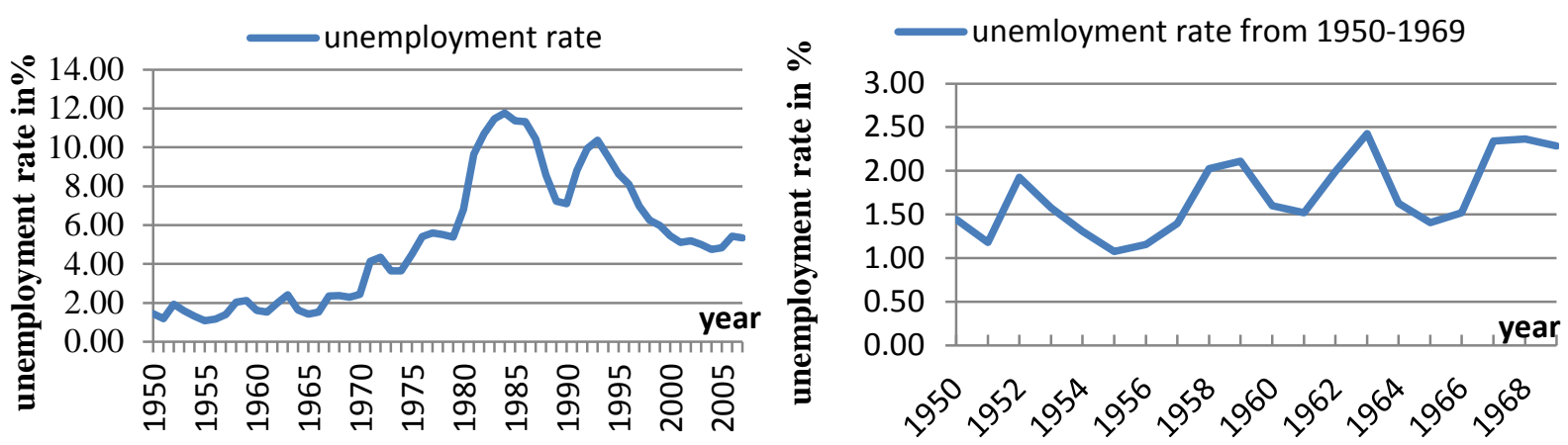

Fig. 3. Unemployment rate (\%) in UK

Fig. 4. Unemployment rate (\%) from 1950-1969during 1950-2007

To some extent, regarding to significantly different performances, those three indicators were affected by developments in macroeconomic theories and policies in corresponding periods.

But actually, just as Backhouse argued, macroeconomic theories themselves have far more limited roles to play towards British economic performances. Instead, external environments seem to be more significant and inseparable than imagine especially for an open economy like UK. (Backhouse, 1983[3])In another aspect, performances are also largely related with how politicians actually implement the policies. (Chrystal \& Price, 1994[4])

\section{Impacts of the External Circumstances}

In neo-Keynesian's dominant period (1950-1969), full-employment was the main economic objective using demand-management policies. Unemployment rates seemed successfully stable around $2 \%$ (Fig.4) which was even known as golden age comparing with before and after in Table1. (Clarke\&Miller,2015[6])

Table 1. UK unemployment rate in Keynesian's Golden Age

\begin{tabular}{|l|c|c|}
\hline & Period & $\%$ \\
\hline Pre-golden age & $1921-1938$ & 13.4 \\
\hline Keynesian golden age & $1950-1969$ & 1.6 \\
\hline Post-golden age & $1970-1993$ & 6.7 \\
\hline
\end{tabular}

But some scholars argued that this good performance wasn't necessarily by direct contributions of Keynesian's low unemployment-goaled policies. Instead, they attributed it to two significant features of the post-war period--the boom of world economy's stimulus for employment and more favourable investment opportunities created by rapid technological advance.(Middleton,1987[7])

So actually, Keynesian's contributions even seemed to be indirect and the good performances can't be separated from highly fortunate set of circumstances.(Tomlinson,1985[8])

From monetarists' view, this demand management policy with full-employment goal should be totally rejected for its neglect to control the money supply.(Sloman,Wride,\&Garratt,2015[2])

Unfortunately, inflation rates(Fig. 5) were actually stable around 5\% under various wage and price policies to maintain competitiveness, except for 1951-52's 10\% due almost to Korean War in June 1950(Mills,1997[9]). 
The stagflation in 1970s enabled monetarists to gain credibility for their criticisms that monetary expansion is the by-product of "full-employment" fiscal policy(Arestis\&Driver,1983[10]), so that Keynesian should be responsible for this high British inflation.(Laidler,1976[11])

But besides Keynesian's ignorance of the role of money in economy (Sherman,1998[12]) and adaptive expectations of people, during late 1960s, it was actually a worldwide phenomenon(Backhouse,1983[3]) that inflation began to show a trend of accelerating which influenced UK badly as an open economy.(Chrystal\&Price,1994[4])This booming trend can be seen in other main countries in 1966-1970 (Fig. 6)(Source: (OECD, 2017)[13]).

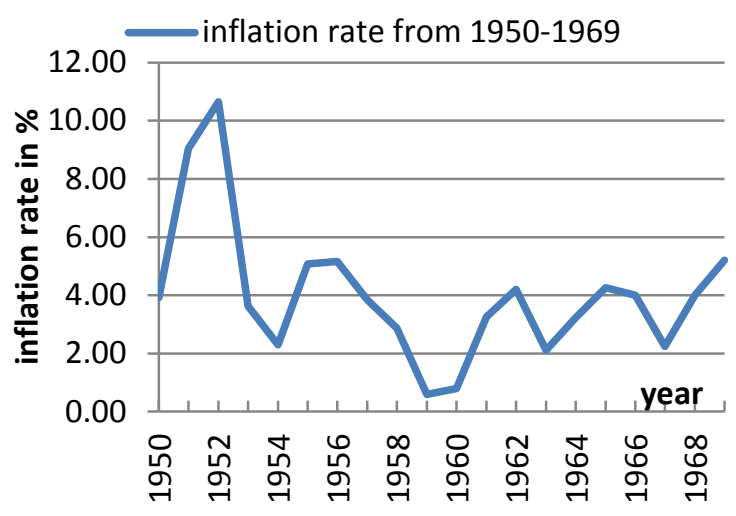

Fig. 5. Inflation rate (\%) from 1950-1969

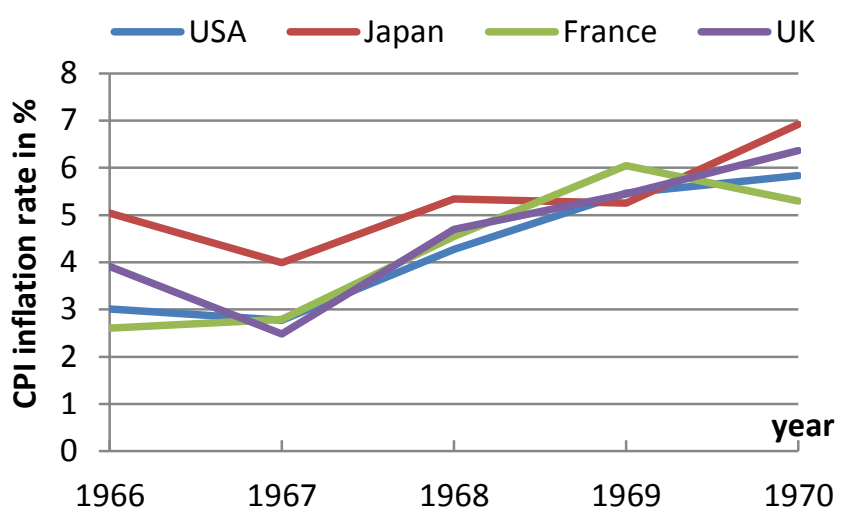

Fig. 6: Inflation rate (\%) between 1966-1970

With oil price rising in 1973 caused by war between Israel and Egypt, UK was dragged into an even worse place as an importer (Roger,2013[14]), along with other series of coincidence e.g. US's high spending in Vietnam War.(Backhouse,1991[5])

Meanwhile, the slow-down of world trade added nearly 50 thousand to the natural-level-ofunemployment before 1979 which largely contributed to the unemployment rate's increasing but still near 5\%(Fig. 7).(Matthews\&Minford,1996[15])
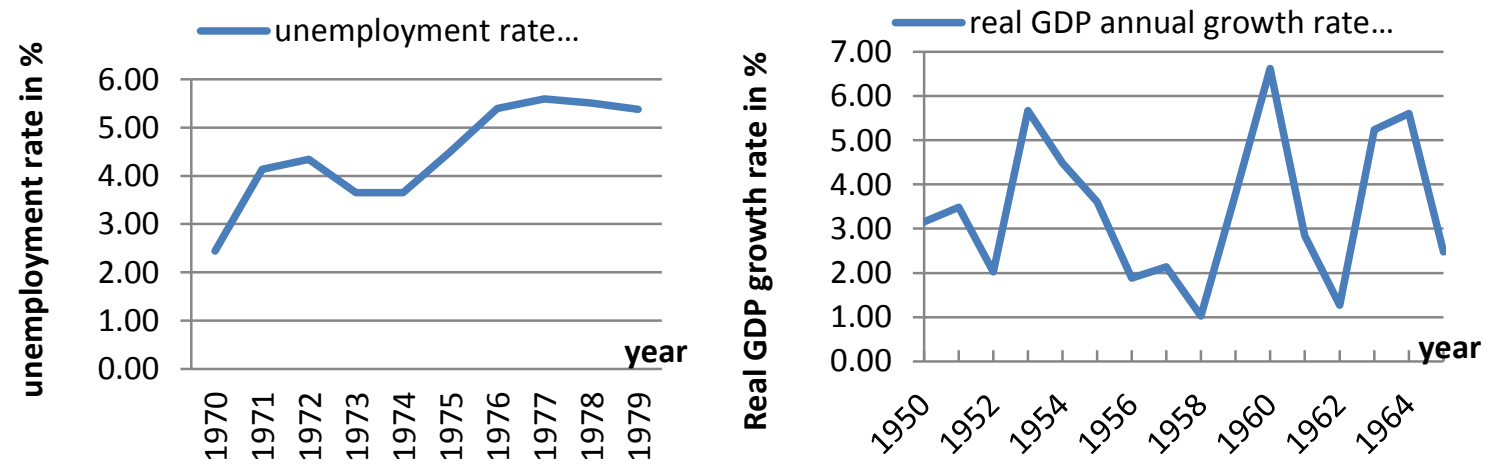

Fig. 7. Unemployment rate (\%)

Fig. 8. Real GDP annual growth rate (\%)from 1970-1979between 1950-1965

Moreover, after Keynesian's golden period, too much was expected of these policies and their inability to achieve these expectations made them more vulnerable when faced by combined challenges posed by unfortunate environments, monetarist economics and changes in political attitudes. (Backhouse,1983[3])So, it seems not wise to either totally attribute the achievement of low unemployment or put the responsibility of stagflation on Keynesian's theory and policy as a whole. Instead, it gives evidence that the combination of economic circumstances is extremely important to be considered when evaluating the performance of the policy or theory itself. 
Similarly, in great moderation during 2000s, the lucky set of circumstances like relative stable industrial structure with fewer economic shocks enabled the possibility of the stable economy, but when unfortunate crisis started from American Wall Street, British economy soon ran into trouble in 2008.(Sloman, Wride,\&Garratt,2015[2])

\section{How Politicians Implemented the Policies}

Besides, sometimes performances were also related with how politicians implemented the policies.

In part, it may reasonable to blame macroeconomic policies for providing opportunities for political-purposed interventions, but authorities must take responsibilities for their actions.(Chrystal\&Price, 1994[4])

One example is demand management policy and its potential of giving authorities techniques to manipulate economy for own interests of elections which were known as "stop-go" policies (Bufton,2004[16]).It did directly cause 3 fluctuations of the business cycle as could be seen around 1955, 1959 and 1964 with GDP growth rate reaching the peaks(Fig.8)(Floud\&Johnson,2004[17]).

\section{External Impacts and Political Implements during Thatcher's Period}

Though suffering from elections in 1950-60, the volatility of economic growth was actually greater in 1980s(Fig. 9), especially the severer recession in 1981which UK suffered more than other countries related with external effects. The implementing policies also affected performances during Thatcher's period.(Coutts \& Gudgin, 2015[18])
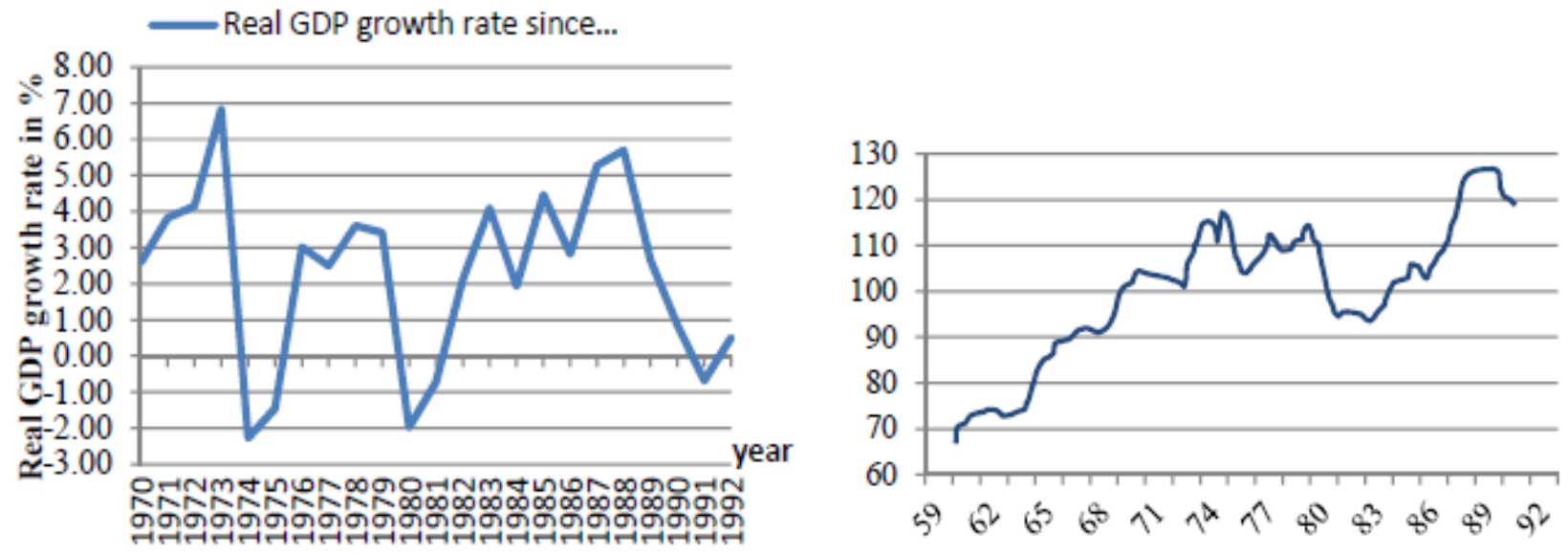

Fig. 9. Real GDP growth rate (\%)since 1970-1992

Fig. 10.UK Manufacturing output index from 1959-1989 (1985=100)

Economists such as Niehans (1981)[19], Buiter and Miller(1981)[20]normally believed that 1981 'srecession was caused by falling competitiveness of sterling due to the tight monetary policy under Thatcher's government from 1979 despite the rapid growth of M3.But later(1983)[21], they admitted that evidences of slow M0 growth and interest rates couldn't support it fully.

Actually, the strength of sterling was arguably having appreciated since 1976 when north-sea oil enabled UK to change from importer to exporter.(Maynard,1988[22])

During the second oil shock, sterling appreciation with oil production rising seemed reap full benefits from oil exporting but also mainly contributed to further sterling strengthening. Thus, it profoundly reduced manufacturing export competitiveness(Table-2) which resulted in firms' cutting productions and manufacturing output falling in 1978-80(Figure-10).(Backhouse, 1983[3])

UK real export's ratio to EEC in base prices (1975 prices \& exchange rates) fell n 1978-80, not using the one in current prices and exchange rates because the export value can be affected by the rising exchange rates. 
Meanwhile, increasing trend of deindustrialization also caused unemployment rise(Fig. 11) since 1979 which also contributed to the falling demand and the recession.(Crafts,1996[23])

Moreover, from 1979, the monetary targets were actually only slightly tighter than those inherited from previous labour government (Chrystal\&Price,1994[4]).

Many true monetarists even doubted if Mrs.Thatcher is a monetarist as herself labelled. Because in practice during 1979-1992, Thatcher government largely ignored its own monetary target but opted for a very costly exchange rate target. Thus, the inflation rates actually didn't seem to be better than Keynesian's period (compareFig.12-1\&12-2) though monetarism's aim was to generate a low inflation environment. (Chrystal\&Price,1994[4])

Table 2: UK Exports, 1978-80 (UK Exports as percentages of EEC exports)

\begin{tabular}{|c|c|}
\hline Year & 1975 prices and exchange rates \\
\hline 1978 & 15.7 \\
\hline 1979 & 15.2 \\
\hline 1980 & 15.0 \\
\hline
\end{tabular}

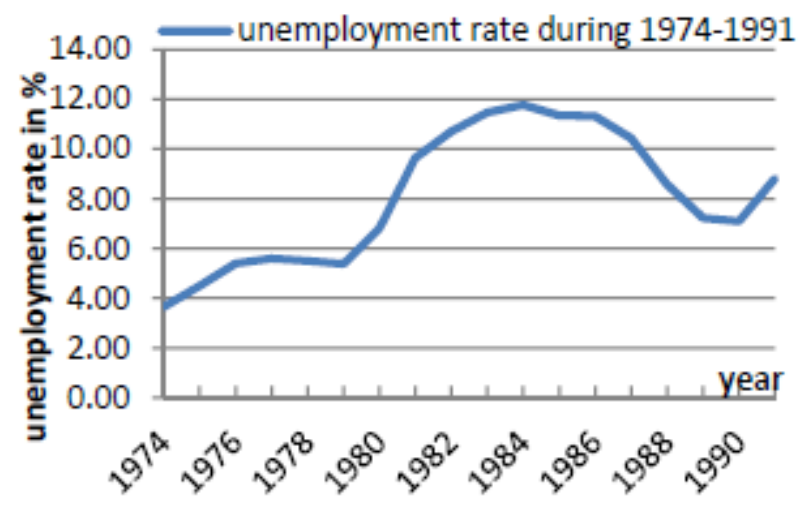

Fig. 11. Unemployment rate (\%) during 1974-1991

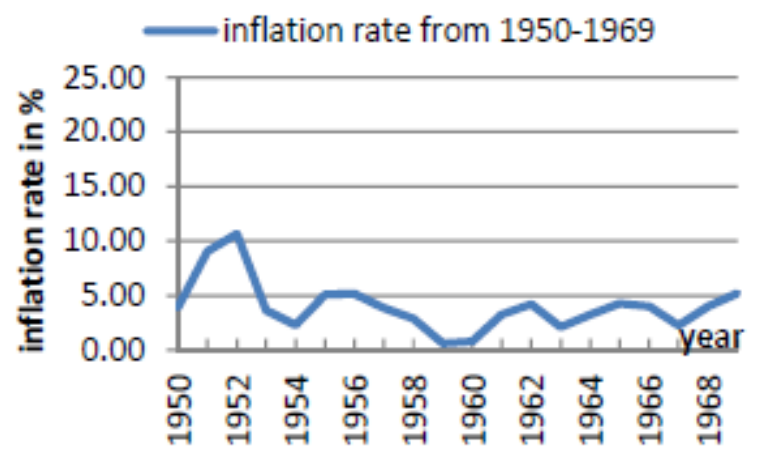

Fig. 12-1. Inflation rate (\%) from 1950-1969

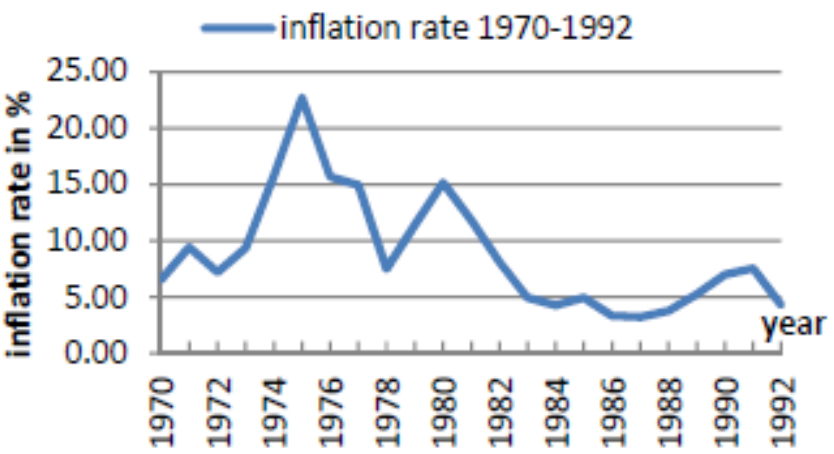

Fig. 12-2. Inflation rate (\%) during 1970-1992

Therefore, some economists argued that irresponsible monetary policies had the role in major recessions and performances during 1979-1992 rather than the theory itself. Monetarism may be blameless but the politicians who campaigned under the Monetarists banner can't be.(Chrystal\&Price, 1994[4])

\section{Summary}

In conclusion, development in macroeconomic theories did relate to evolutions of the three indicators, but the role is actually very limited. Both the set of external circumstances and how politicians actually implementing the policies are also inseparable to the economic performances in corresponding periods. 


\section{References}

[1] Thomas, R., \& Dimsdale, N. (2016). Three Centuries of Data - Version 2.3. http://www.bankofengland.co.uk/research/Pages/onebank/threecenturies.aspx [Accessed on 27 March 2017].

[2] Sloman, J., Wride, A., \& Garratt, D. (2015). Economics (9th ed.). Harlow: Pearson Education Limited., 2015.

[3] Backhouse, R. (1983). Macroeconomics and the British Economy. Oxford: Martin Robertson \& Company Ltd., 1983.

[4] Chrystal, K. A., \& Price, S. (1994). Controversies in Macroeconomics (3rd ed.). Hertfordshire: Prentice Hall., 1994.

[5] Backhouse, R. E. (1991). Applied UK Macroeconomics. Basil Blackwell, Oxford., 1991.

[6] Clarke, P., \& Miller, R. C. B. (2015). BRITAIN'S BAKER'S DOZEN OF DISASTERS: The UK's thirteen worst economic policy mistakes since 1900. IEA Discussion Paper(No.65)., 2015.

[7] Middleton, R (1987) The rise and fall of the managed economy. ReFRESH, 1987, vol 5, pp. 5-8.

[8] Tomlinson, J. (1985). British Macroeconomic Policy Since 1940. New York: Routledge., 1985.

[9] Mills, J. (1997). Tackling Britain's False Economy: Unemployment, Inflation, Slow Growth. Hampshire Macmillan Press LTD., 1997.

[10] Arestis, P., \& Driver, C. (1983). UK unemployment and Post-Keynesian remedies. Metroeconomica, 1983, 35(3), 275-291.

[11] Laidler, D. (1976). Inflation in Britain: A Monetarist Perspective. The American Economic Review, 1976, 66(4), 485-500.

[12] Sherman, A. (1998). Economic policies: still shackled by post-war euphoria? Economic Affairs, 1998, 18(2), 47-49.

[13] OECD (2017). Inflation (CPI) (indicator). doi:10.1787/eee82e6e-en (Accessed on 24 March 2017).

[14] Rogers, C. (2013). Crisis, Ideas, and Economic Policymaking in Britain during the 1970s Stagflation. New Political Economy, 2013, 18(No. 1), 1-20.

[15] Matthews, K., \& Minford, P. (1996). British inflation and unemployment in the 1970s: a model-based decomposition. Applied Economics, 28(1), 1996, 103-115.

[16] Bufton, M. (2004). Britain's Productivity Problem, 1948-1990. New York: Palgrave Macmillan.,2004.

[17] Floud, R., \& Johnson, P. (2004). The Cambridge Economic History of Modern Britain (Vol. 3). Cambridge: Cambridge University Press., 2004.

[18] Coutts, K., \& Gudgin, G. (2015). The Macroeconomic Impact of Liberal Economic Policies in the UK. University of Cambridge Centre for Business Research, Judge Business School., 2015.

[19] Niehans, J. (1981). The appreciation of sterling- causes, effects and policies. Money Study Group Discussion Paper. ,1981.

[20] Buiter, W., \& Miller, M. (1981a). The Thatcher experiment: the first two years. Brooking Paper on Economic Activity(Part 2),1981, 315-367.

[21] Buiter, W., \& Miller, M. (1983). Changing the rules: Economic consequences of the Thatcher regime. Brooking Paper on Economic Activity(Part 2),1983, 305-365. 
[22] Maynard, G. (1988). The economy under Mrs Thatcher. Oxford, UK: Basil Blackwell Ltd., 1988.

[23] Crafts, N. (1996). Denationalization and Economic Growth. The Economic Journal, 1996, 106(434), 172-183. 